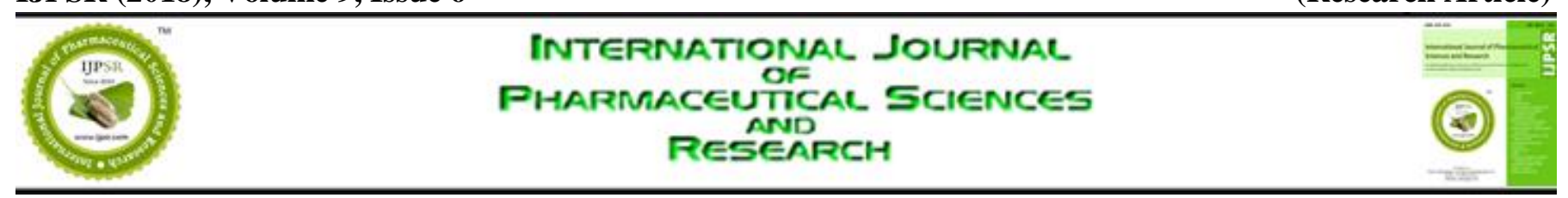

Received on 06 September, 2017; received in revised form, 17 February, 2018; accepted, 04 March, 2018; published 01 June, 2018

\title{
METHOD DEVELOPMENT AND VALIDATION FOR THE ESTIMATION OF AMBROXOL HCI IN PHARMACEUTICAL DOSAGE FORM
}

Padmavathi P. Prabhu *, Paramita Das and N. Shukla Khushboo

Department of Pharmaceutical Chemistry, Srinivas College of Pharmacy, Valachil, Mangalore - 574143, Karnataka, India.

\section{Keywords:}

Ambroxol $\mathrm{HCl}$, Gibb's reagent, p-Dimethyl Amino Benzaldehyde, Beer's law

Correspondence to Author:

Dr. Padmavathi P. Prabhu

Professor,

Department of Pharmaceutical Chemistry, Srinivas College of Pharmacy, Valachil, Mangalore 574143, Karnataka, India.

E-mail: padmapprabhu@gmail.com

\begin{abstract}
Rapid, sensitive, specific and validated colorimetric methods have been developed for the quantitative estimation of ambroxol $\mathrm{HCl}$ in bulk and dosage form. The current method was developed based on oxidation of ambroxol with Gibb's reagent (method I) and p-diethyl amino benzaldehyde in toluene (method II). The formed intense colour complex was measured at $537.2 \mathrm{~nm}$ and $438.4 \mathrm{~nm}$ respectively. Under optimized experimental conditions, Beer's law is obeyed in concentration range $5-30 \mu \mathrm{g} / \mathrm{ml}$ for both the methods with regression co-efficient 0.9994 and 0.9992. Recovery studies were conducted by standard addition method to confirm the accuracy of the method. The LOD and LOQ for the estimation of ambroxol were found as $0.0773,0.2343$ for method I and $0.0667,0.2021$ for method II respectively. The proposed method was validated as per ICH guidelines.
\end{abstract}

INTRODUCTION: Spectrometric methods are a large group of analytical methods that are based on atomic and molecular spectroscopy ${ }^{1}$. Colorimetric assays generally consists of adding a reagent to the assay preparation or to the substance being tested, to produce a colour that is compared with that of a standard preparation that has been prepared simultaneously and contains approximate quantity of the reference standard ${ }^{2}$. In general, in analysis the first step is to determine the nature of the sample that is complete qualitative information and then further proceed for quantitative information by accuracy, LOD, LOQ etc. ${ }^{3}$ Method validation is the process to confirm that the analytical procedure employed for a specific test is suitable for its intended use ${ }^{4}$.

\begin{tabular}{|l|c|}
\hline QUICK RESPONSE CODE & DOI: \\
& $\begin{array}{c}\text { Article can be accessed online on: } \\
\text { www.ijpsr.com }\end{array}$ \\
\hline DOI link: http://dx.doi.org/10.13040/JJPSR.0975-8232.9(6).2550-53 \\
\hline
\end{tabular}

The parameters for method validation have been defined in different working groups of national and international committees and are described in the literature 5. Ambroxol is a clinically proven systematically active mucolytic agent. It is freely soluble in water, practically insoluble or very slightly soluble in ethanol (96 per cent) and in methylene chloride ${ }^{6,7,8}$. The literature survey reveals that few methods are reported for the determination of Ambroxol Hydrochloride such as thin layer chromatography, RP isocratic HPLC, UHPLC etc. ${ }^{10}$.

Validation characteristics evaluated are Specificity, Accuracy, Precision, Limit of detection, Limit of quantitation, Linearity, Range, Ruggedness and Robustness. The method is based on formation of a purple coloured chromogen by the interaction of Ambroxol Hydrochloride with Gibb's reagent (Method IA) and light greenish yellow colour chromogen with p-dimethylamino benzaldehyde reagent and toluene (Method IB) under acidic condition. 
MATERIALS AND METHODS: Shimadzu UV spectrophotometer 1700 and Jasco V-630 spectrophotometer with $1 \mathrm{~cm}$ matched quartz cells was used for all spectral and absorbance measurements. Pure drug was procured from local pharmaceutical industry. Basic apparatus like calibrated volumetric flasks, pipette, beakers and graduated pipettes were used.

\section{Experimental:}

Preparation of Stock Solutions: Accurately weighed $100 \mathrm{mg}$ of Ambroxol $\mathrm{HCl}$ was dissolved in $100 \mathrm{ml}$ ethanol to give a concentration of 1000 $\mu \mathrm{g} / \mathrm{ml}$. The final concentration was brought to 100 $\mu \mathrm{g} / \mathrm{ml}$ for Methods A and B.

\section{Method IA:}

- $0.1 \%$ Gibb's reagent

- $0.2 \%$ Borax

\section{Method IB:}

- $1 \%$ Paradimethyl amino benzaldehyde

- Toluene

Assay Procedure for the Determination of Ambroxol HCl:

Method IA: Seven $10 \mathrm{ml}$ volumetric flasks were taken. $1 \mathrm{ml}, 2 \mathrm{ml}, 3 \mathrm{ml}, 4 \mathrm{ml}, 5 \mathrm{ml}, 6 \mathrm{ml}$ of working standard of Ambroxol $\mathrm{HCl}$ was added in each volumetric flask. Then $1.0 \mathrm{ml} 0.1 \%$ of Gibbs reagent solution and $1 \mathrm{ml}$ of $0.2 \%$ Borax were added and left for $10 \mathrm{~min}$. Volume was made up to mark with Ethanol. Absorbance was taken at 537.2 $\mathrm{nm}$.

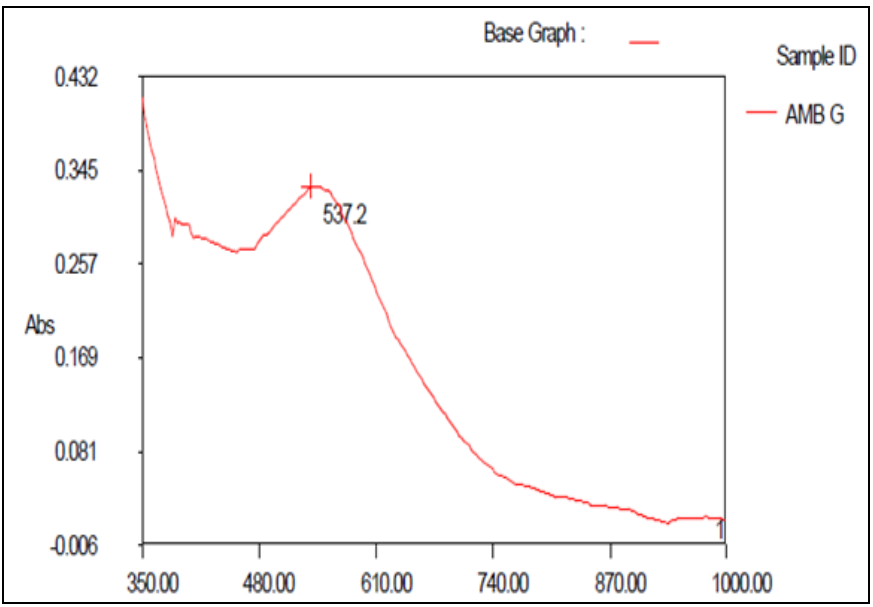

FIG. 1: ABSORPTION SPECTRUM OF COLORED CHROMOGEN IN METHOD IA
Method IB: Seven $10 \mathrm{ml}$ volumetric flasks were taken. $1 \mathrm{ml}, 2 \mathrm{ml}, 3 \mathrm{ml}, 4 \mathrm{ml}, 5 \mathrm{ml}, 6 \mathrm{ml}$ of working standard $(10 \mu \mathrm{g} / \mathrm{ml})$ of Ambroxol $\mathrm{HCl}$ was added in each volumetric flask. To flask, $2 \mathrm{ml}$ of $1 \%$ PDAB, $0.3 \mathrm{ml}$ of toluene and $0.02 \mathrm{ml}$ of $\mathrm{H}_{2} \mathrm{SO}_{4}$ were added. The volume in flask was made up to the mark with ethanol. The absorbance was measured against the reagent blank at $438.4 \mathrm{~nm}$.

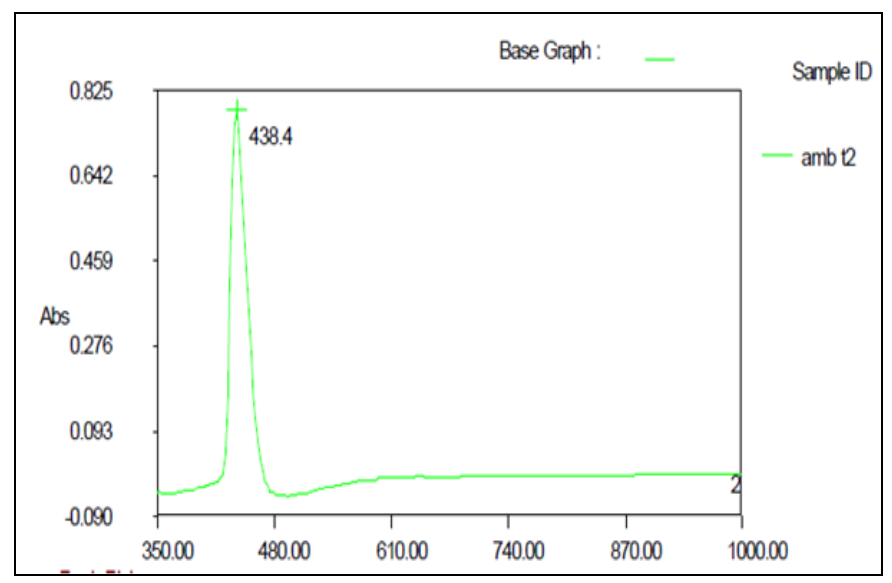

FIG: 2 ABSORPTION SPECTRUM OF COLORED CHROMOGEN IN METHOD IB

Assay of Pharmaceutical Formulations: Weighed accurately tablet powder equivalent to $100 \mathrm{mg}$ and transferred into $100 \mathrm{ml}$ volumetric flask and Ambroxol $\mathrm{HCl}$ was extracted in $10 \mathrm{ml}$ of ethanol. The solution was then filtered and the filtrate was then made up to $100 \mathrm{ml}$ with ethanol to get 1000 $\mu \mathrm{g} / \mathrm{ml}$ concentration. This solution was further diluted to get concentration of $10 \mu \mathrm{g} / \mathrm{ml}$.

Appropriate aliquots of drug solution were taken. The individual assay procedure was carried out for the estimation of drug contents in tablets. The concentration of the drug in the tablets was calculated using calibration curve. The recovery experiment was carried out by standard addition method. The values of optical and regression terms of analysis are given in Table 1.

RESULTS AND DISCUSSION: Method IA, Ambroxol $\mathrm{HCl}$ gives purple coloured chromogen with Gibb's reagent, which showed $\lambda_{\max }$ at 537.2 $\mathrm{nm}$.

In Method IB, the drug was reacted with Paradimethyl amino benzaldehyde which produce greenish yellow colour chromogen which showed $\lambda_{\max }$ at $438.4 \mathrm{~nm}$. 
The optical characteristics such as absorption maxima and Beer's law limits for these methods are presented in Table 1. The regression analysis using the method of least squares was made for the slope (a) and intercept (b) obtained from different concentrations are summarized in Table 1. The precision and accuracy were found by analyzing six replicate samples containing known amounts of the drug and the results are summarized in Table 1.

TABLE 1: ABSORPTION MAXIMA AND BEER's LAW LIMITS

\begin{tabular}{ccc}
\hline Parameter & Result of Method IA & Result of Method IB \\
\hline$\lambda_{\max }(\mathrm{nm})$ & 537.2 & $438.45-30$ \\
Beer's law limit & $5-30$ & $\mathrm{y}=\mathrm{bx}+\mathrm{a}: \mathrm{y}=0.0207 \mathrm{x}-0.0005$ \\
Regression Equation* $(\mathrm{y})$ & $\mathrm{y}=\mathrm{bx}+\mathrm{a}: \mathrm{y}=0.0324 \mathrm{x}-0.0014$ & 0.0207 \\
Slope $(\mathrm{b})$ & 0.0324 & 0.0005 \\
Intercept $(\mathrm{a})$ & 0.0014 & 0.0318 \\
Correlation coefficient $\left(\mathrm{R}^{2}\right)$ & 0.9994 & 0.0966 \\
Limit of Detection $(\mu \mathrm{g} / \mathrm{ml})$ & 0.0101 & $96.83 \pm 0.0152$ \\
Limit of quantitation $(\mu \mathrm{g} / \mathrm{ml})$ & 0.0308 & $0.19933 \pm 0.000251$ \\
Accuracy $(\%$ Recovery $\pm \mathrm{SD})$ & $98.88 \pm 0.015$ & $0.19927 \pm 000351$ \\
Precision ( Reproducibility) & & \\
Intraday (\% Recovery $\pm \mathrm{SD})$ & $0.330267 \pm 0.000208$ & \\
Interday $(\%$ Recovery $\pm \mathrm{SD})$ & $0.3303 \pm 000321$ & \\
\hline
\end{tabular}

$\mathrm{y}=\mathrm{bx}+\mathrm{a}$, where $\mathrm{y}$ is the absorbance and $\mathrm{x}$ is the concentration of $\mathrm{N}$-acetylcysteine in $\mu \mathrm{g} / \mathrm{ml}$.

Recovery Studies: Weighed accurately tablet powder equivalent to $100 \mathrm{mg}$ and transferred into $100 \mathrm{ml}$ volumetric flask and Ambroxol $\mathrm{HCl}$ was extracted in $10 \mathrm{ml}$ of ethanol. The solution was then filtered and the filtrate was then made up to $100 \mathrm{ml}$ with ethanol to get get $1000 \mu \mathrm{g} / \mathrm{ml}$ concentration. This solution was further diluted to get concentration of $10 \mu \mathrm{g} / \mathrm{ml}$. To keep an additional check on accuracy of developed assay method, analytical recovery experiments were performed. The different solutions of different concentrations like 2, 4 and $6 \mu \mathrm{g} / \mathrm{ml}$ were prepared in case of both pure drug solution and the formulation extract solution and these solutions were subjected to analysis by above developed method. The six such samples were prepared and average of that readings taken for calculation of \% recovery. This is reported in following Table 2.

TABLE 2: RECOVERY STUDIES

\begin{tabular}{ccccc}
\hline Method & Sample & Labelled amount $(\mathbf{m g})$ & Amount found $(\mathbf{m g})$ & \% Recovery \\
\hline IA & Ambroxol HCl & 30 & 28.85 & 96.16 \\
IB & Ambroxol HCl & 30 & 29.15 & 97.16 \\
\hline
\end{tabular}

CONCLUSION For routine analytical purpose, it is always necessary to establish methods capable of analyzing huge number of samples in a short time period with due accuracy and precision. Few analytical methods appeared in the literature for the determination of Salbutamol Sulphate. Proposed method makes use of simple reagent, which an ordinary analytical laboratory can afford. The method was found to be simple, precise, economic and less time consuming. In the present investigation, colorimetric method for the quantitative estimation of Salbutamol Sulphate in bulk drug and pharmaceutical formulations has been developed.

ACKNOWLEDGEMENT: The authors are thankful to the authorities of Srinivas College of pharmacy and A. Shama Rao Foundation,
Mangalore for providing the facilities to carry out the present work.

\section{CONFLICT OF INTEREST: Nil}

\section{REFERENCES:}

1. Beckett AH and Stenlake JB: Practical pharmaceutical chemistry. $4^{\text {th }}$ Ed. New Delhi: CBS Publishers and Distributors 1997; 275-81.

2. Kasture AV, Wadodkar SG, Mahadik KR and More HN: Pharmaceutical Analysis. 11 ${ }^{\text {th }}$ Ed. Nirali Prakashan 2004; 169-81.

3. Meritt W: Settle. Instrumental methods of analysis. $7^{\text {th }}$ ed. 1989; 118-72.

4. Sharma PP: Validation in pharmaceutical industry 2007 ; 1 : 361-82.

5. Nash RA and Alfred HW: Pharmaceutical process validation 2008; 3: 507-23.

6. British pharmacopeia; published by British Pharmacopoeia Commission Office; London; 2009; 5345-50. 
7. Bhatia NM, Ganbavale SK, Bhatia MS, More HN and Kokil SU: RP-HPLC and spectrophotometric estimation of Ambroxol $\mathrm{HCl}$ and cetrizine $\mathrm{HCl}$ in combined dosage form. Ind J Pharm Sci 2008; 70(5): 603-8.

8. Prabu SL, Srinivasan M, Thiagarajan S and Marina Q: Simultaneous determination of gatifloxacin and ambroxol hydrochloride in a tablet formulation by liquid chromatography. Pharm Anal Acta 2010; 1: 110.

9. Trivedi RK, Patel MC and Jadhav SB: A rapid, stability indicating RP-UPLC method for simultaneous determination of ambroxol hydrochloride, cetirizine hydrochloride and antimicrobial preservatives in liquid pharmaceutical formulation. Sci Pharm. 2011; 79(3): 52543.

10. Selvadurai M, Kumar JR and Dhanara SA. Development and validation of a high- performance liquid chromatographic, and an ultraviolet spectrophotometric method for determination of Ambroxol hydrochloride in pharmaceutical preparations. J Adv Pharm Tech Res. 2013; 4(1): $65-8$.

How to cite this article:

Prabhu PP, Das P and Khushboo NS: Method development and validation for the estimation of Ambroxol $\mathrm{HCl}$ in pharmaceutical dosage form. Int J Pharm Sci Res 2018; 9(6): 2550-53. doi: 10.13040/IJPSR.0975-8232.9(6).2550-53.

All @ 2013 are reserved by International Journal of Pharmaceutical Sciences and Research. This Journal licensed under a Creative Commons Attribution-NonCommercial-ShareAlike 3.0 Unported License.

This article can be downloaded to ANDROID OS based mobile. Scan QR Code using Code/Bar Scanner from your mobile. (Scanners are available on Google Playstore) 